\title{
KEMAMPUAN PEMECAHAN MASALAH MATEMATIS SISWA KELAS VIII SMP MENGGUNAKAN PENDEKATAN MATEMATIKA REALISTIK INDONESIA
}

\author{
Putriana $^{1}$, Rani Refianti ${ }^{2}$, Elya Rosalina ${ }^{3}$ \\ ${ }^{I}$ STKIP PGRI Lubuklinggau, Indonesia, putrianarosidin@gmail.com \\ ${ }^{2}$ STKIP PGRI Lubuklinggau, Indonesia, ranirefianti834@gmail.com \\ ${ }^{3}$ STKIP PGRI Lubuklinggau, Indonesia, elyarosalina25@gmail.com
}

\section{ARTICLE INFORMATION \\ Received: November 01, 2020 \\ Revised: December 08, 2020 \\ Available online: December 31, 2020}

KEYWORDS

PMRI, Pemecahan Masalah Matematis

PMRI, Mathematical Problem Solving

\section{CORRESPONDENCE}

\section{Rani Refianti}

E-mail:

ranirefianti834@gmail.com

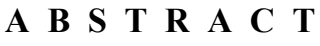

Penelitian ini bertujuan untuk mengetahui kemampuan pemecahan masalah matematis siswa pada pembelajaran matematika menggunakan Pendekatan Pendidikan Matematika Realistik Indonesia (PMRI). Teknik Pengumpulan data menggunakan teknik tes yang dianalisis menggunakan uji-t pada taraf signifikan $\alpha=5 \%$. Dari hasil post-test kemampuan pemecahan masalah siswa kelas dengan indikator memahami masalah sebesar $93 \%$ berada pada kategori sangat baik, indikator membuat rencana penyelesaian sebesar $73 \%$ dengan kategori baik, indikator melaksanakan rencana sebesar 65\% dengan kategori baik dan indikator memeriksa kembali hasil sebesar 25\% dengan kategori kurang. Setelah mengikuti pembelajaran menggunakan Pendekatan Pendidikan Matematika Realistik Indonesia (PMRI) rata-rata nilai post-test sebesar 70,35 dengan 5 siswa yang sangat baik, 12 siswa yang sudah baik dan 6 siswa yang cukup baik.
\end{abstract}

This study aims to determine the ability of students to solve mathematical problems in mathematics learning using the Indonesian Realistic Mathematics Education Approach (PMRI). The data collection technique used the test technique which was analyzed using the t-test at the significant level $\alpha=5 \%$. From the results of the post-test students' problem solving abilities with indicators of understanding the problem by $93 \%$ were in the very good category, the indicators of making a completion plan were $73 \%$ in the good category, the indicators of implementing the plan were $65 \%$ in the good category and the indicators of checking the results were $25 \%$ with less category. After participating in learning using the Indonesian Realistic Mathematics Education Approach (PMRI) the average post-test score was 70.35 with 5 excellent students, 12 good students and 6 good enough students.

\section{PENDAHULUAN}

Kemajuan pendidikan di Indonesia dapat dikatakan berkembang pesat saat ini. Menurut Indriani \& Imanuel (2018:256) bahwa dalam kemajuan dunia pendidikan matematika adalah salah satu mata pelajaran yang dapat menunjang Ilmu Pengetahuan dan Tekhnologi (IPTEK). Menurut 


\section{Journal of Mathematics Science and Education \\ ISSN (Print) 2623-2375 | ISSN (Online) 2623-2383 । \\ DOI : https://doi.org/10.31540/jmse.v3i1.1097 \\ Penerbit : LP4MK STKIP PGRI Lubuklinggau}

Setiawati (dalam Rahman, 2017:27) menyatakan bahwa rendahnya kemampuan pemecahan masalah yang dapat mempengaruhi hasil belajar dalam pembelajaran matematika disebabkan karena materi ajar yang diberikan guru kepada siswa sedikit atau kurangnya penekanan matematika melalui konteks kehidupan sehari-hari, guru memberikan materi pelajaran dengan metode yang kurang menarik sehingga siswa mengalami kesulitan dalam menguasai materi matematika dengan baik yang menyebabkan siswa kurang menggunakan nalar dan masih kesulitan ataupun lambat memahami soal yang diberikan secara lengkap dalam kemampuan pemecahan masalah matematis siswa.

Guru menggunakan berbagai model pembelajaran akan tetapi lebih sering menggunakan metode konvensional (ceramah) pada materi tertentu, hal tersebut membuat siswa masih membayangkan materi yang diberikan oleh guru dan siswa merasa bosan ketika proses pembelajaran serta dalam menyelesaikan soal yang diberikan siswa mengalami kesulitan dalam memahami soal cerita dan menuliskan jawaban secara tidak lengkap. Selanjutnya peneliti memberikan soal tes kemampuan pemecahan masalah untuk melihat bagaimana kemampuan siswa dalam menyelesaikan soal berdasarkan indikator pemecahan masalah. Pendekatan PMRI dipilih terhadap kemampuan pemecahan masalah matematis karena pendekatan ini termasuk salah satu pendekatan yang terdapat dalam kurikulum 2013, dalam pembelajaran matematika perlu adanya kegiatan manusia yang lebih menekankan pada aktivitas belajar siswa dalam mencari, menemukan, dan membengun sendiri pengetahuannya. Sehingga mengutamakan pembelajaran lebih berpusat kepada siswa melalui pemberian masalah kontekstual membuat siswa lebih memahami kaitan erat konsep matematika dengan aktivitas sehari-hari. Sebagaimana yang dikemukakan oleh Marhama (dalam Lestari, 2014:3) bahwa pendekatan PMRI sangat cocok dalam pembelajaran matematika karena memiliki karakteristik serta prinsip yang membantu perkembangan secara optimal. Contohnya, memberikan ruang kepada siswa dalam mengemukakan pendapat, mengaitkan konsep matematika kedalam dunia nyata, dan membuat model matematika yang dapat mempermudah dalam menyelesaikan masalah matematis.

Menurut Sembiring (dalam Rahayu, 2017:155) bahwa pendekatan PMRI diadopsi dari RME karenanya prinsip yang ada dalam pendekatan PMRI sama dengan RME. ada beberapa hal yang membedakan pendekatan PMRI dan RME yaitu konteks, budaya, sistem sosial dan alam. Agar dapat mendukung kesuksesan dalam implementasi pendekatan PMRI proses pembelajaran membutuhkan kurikulum yang sesuai dengan konteks Indonesia. Sedangkan Menurut Husna (dalam Indriani \& Imanuel, 2018:258) bahwa pendekatan PMRI menggunakan suatu masalah kontekstual yang menjadi 


\section{Journal of Mathematics Science and Education \\ ISSN (Print) 2623-2375 | ISSN (Online) 2623-2383 । \\ DOI : https://doi.org/10.31540/jmse.v3i1.1097 \\ Penerbit : LP4MK STKIP PGRI Lubuklinggau}

titik awal pembelajaran sesuai dengan pengalaman yang didapat siswa sehingga siswa bisa menghubungkan dirinya dalam aktifitas belajar menjadi konteks yang dapat menjadi bahan sebagai pembentukan konsep, dimulai dari sesuatu yang bersifat konkrit atau kontekstual dan dekat dengan pengalaman siswa, sehingga siswa dapat mengembangkan model matematika sendiri. Dapat disimpulkan bahwa Pedekatan PMRI merupakan pemberian masalah realistik dari lingkungan siswa sebagai titik awal atau simulasi dalam proses pembelajaran matematika untuk menemukan ide ataupun konsep yang dapat membangun pengetahuan siswa membentuk model matematika sehingga siswa menemukan kembali aturan, sifat-sifat dan rumus-rumus matematika dari pengalaman siswa sendiri. Prinsip pendekatan PMRI yaitu aktivitas siswa dimulai dari menemukan kembali melalui pemberian masalah kontekstual sebagai simulasi pembelajaran, selanjutnya dari dunia real siswa menghubungkan kembali ke dunia nyata melalui topik-topik matematika yang ada di dalam masalah kontekstual, siswa menemukan cara penyelesaian melalui berbagai jenjang dari masalah kontekstual yang diberikan, siswa berinteraksi dengan teman ataupun guru untuk menarik kesimpulan tentang materi yang dipelajari.

Berdasarkan uraian di atas, maka diharapkan dengan Pendekatan PMRI dapat membuat proses pemecahan masalah matematis di kelas membuat siswa lebih mudah menerjemahkan soal cerita kedalam bahasa matematika serta penyelesaian memuat indikator kemampuan pemecahan masalah matematis. Pernyataan-pernyataan tersebut menguatkan bahwa pendekatan PMRI merupakan pendekatan yang strategis dan sesuai dalam proses pembelajaran matematika, khususnya dalam pemecahan masalah matematis.

\section{METODE}

Rancangan penelitian yang digunakan dalam penelitian ini adalah eksperimen semu kategori Pretest and Postest Group Teknik analisis data yang dilakukan antara lain: uji normalitas dan uji hipotesis. Pengambilan sampel dilakukan dengan cara undian. Sebagai sampel dalam penelitian ini adalah kelas VIII.3.

Teknik pengumpulan data yang akan digunakan dalam penelitian ini adalah teknik tes. Tes pada penelitian ini diberikan sebanyak dua kali yaitu sebelum proses pembelajaran (pre-test) dan setelah setelah mengikuti pembelajaran (post-test). Jenis tes yang digunakan dalam penelitian ini berbentuk uraian.

Langkah-langkah pendekatan PMRI yaitu : 


\section{Journal of Mathematics Science and Education \\ ISSN (Print) 2623-2375 | ISSN (Online) 2623-2383 | \\ DOI : https://doi.org/10.31540/jmse.v3i1.1097 \\ Penerbit : LP4MK STKIP PGRI Lubuklinggau}

1. Peneliti memberikan Lembar Kerja Siswa (LKS) dan menjelaskan Indikator Pecapaian Kompetensi (IPK) serta petunjuk penyelesaian pada LKS.

2. Peneliti membentuk kelompok diskusi secara heterogen, tiap kelompok terdiri dari 5-6 siswa.

3. Peneliti meminta siswa untuk mengamati materi pelajaran yang ada dalam LKS.

4. Melalui kegiatan diskusi untuk menyelesaikan masalah melalui beberapa tahap yaitu tahap 1 memberikan masalah realistik, tahap 2 model of (pengembangan model dari masalah realistik yang masih bersifat khusus dari situasi yang diberikan), tahap 3 model for (dari proses generalisasai dan formalisasi model untuk mengarahkan menuju penyelesaian matematika formal.

5. Peneliti memberikan kesempatan kepada siswa untuk mengamati masalah dengan cermat dan berdiskusi dengan kelompoknya untuk menemukan jawaban.

6. Peneliti memberikan ruang kepada siswa untuk bertanya ketika siswa mengalami kesulitan dalam memahami masalah yang diberikan.

7. Menentukan salah satu teman untuk mempresentasikan hasil kerja kelompok.

Melalui Diskusi kelas: Peneliti mengaitkan kembali tentang tujuan pembelajaran seperti yang telah dijelaskan diawal pembelajaran selanjutnya peneliti memberikan kesempatan kepada salah satu siswa yang bersedia mempresentasikan jawaban di depan kelas, siswa menuliskan jawaban di papan tulis dan menjelaskan hasil pekerjaan kelompok kepada siswa lainnya.

\section{HASIL DAN PEMBAHASAN}

Sebelum pelaksanaan Pre-test makam Intrumen soal diujicobakan terlebih dahulu. Berdasarkan hasil perhitungan uji coba instrumen tersebut, maka diperoleh rekapitulasi hasil uji coba instrumen yang terdapat pada Tabel 1 berikut.

Tabel 1. Hasil analisis uji coba instrumen

\begin{tabular}{|c|c|c|c|c|c|c|c|}
\hline No & \multicolumn{2}{|c|}{ Validitas } & \multicolumn{2}{c|}{$\begin{array}{c}\text { Daya } \\
\text { Pembeda }\end{array}$} & \multicolumn{2}{c|}{$\begin{array}{c}\text { Indeks } \\
\text { Kesukaran }\end{array}$} & Keterangan \\
\hline 1 & 0,77 & Valid / tinggi & 0,16 & Buruk & 0,37 & Sedang & Digunakan \\
\hline 2 & 0,90 & Valid / sangat tinggi & 0,2 & Cukup & 0,36 & Sedang & Digunakan \\
\hline 3 & 0,64 & Valid / tinggi & 0,16 & Buruk & 0,28 & Sukar & Digunakan \\
\hline 4 & 0,74 & Valid / tinggi & 0,28 & Cukup & 0,22 & Sukar & Digunakan \\
\hline 5 & 0,73 & Valid / tinggi & 0,26 & Cukup & 0,25 & Sukar & Digunakan \\
\hline
\end{tabular}




\section{Journal of Mathematics Science and Education \\ ISSN (Print) 2623-2375 | ISSN (Online) 2623-2383 | \\ DOI : https://doi.org/10.31540/jmse.v3i1.1097 \\ Penerbit : LP4MK STKIP PGRI Lubuklinggau}

Berdasarkan rekapitulasi hasil uji coba instrumen penelitian pada tabel 2 di atas dapat disimpulkan bahwa soal yang dapat digunakan adalah sebanyak lima soal yaitu soal nomor 1, 2, 3,4, dan 5.

\section{Deskripsi Data Kemampuan Awal}

Pada pertemuan pertama dilakukan tes terhadap kemampuan awal (pre-test) siswa. Pre-test diberikan kepada siswa dengan tujuan untuk mengetahui kemampuan awal pemecahan masalah siswa sebelum dilaksanakan pembelajaran dengan menggunakan pendekatan Pendidikan Matematika Realistik Indonesia (PMRI). Soal yang diberikan berbentuk uraian sebanyak lima butir yang menguji kemampuan pemecahan masalah matematis siswa. Pre-test dilakukan peneliti pada tanggal 23 Juli 2019 sebanyak 23 siswa.

Setelah dilakukan pengolaan data pre-test diketahui bahwa nilai rata-rata kemampuan pemecahan masalah matematis yang diperoleh siswa sebesar 14,70 dengan simpangan baku 7,03. Dari 23 siswa dikelas VIII.3 diperoleh nilai tertinggi sebesar 28 dan nilai terendah sebesar 2. Dari nilai rata-rata tersebut dapat diketahui bahwa kemampuan pemecahan masalah matematis siswa masih sangat rendah.

\section{Deskripsi Data Kemampuan Akhir}

Pada pertemuan terakhir dilakukan tes kemampuan akhir (post-test) yang merupakan kemampuan pemecahan masalah matematis siswa setelah mengikuti proses pembelajaran dengan menggunakan Pendekatan Pendidikan Matematika Realistik Indonesia (PMRI). Pelaksanaan posttest dilaksanakan pada tanggal 06 Agustus 2019 dengan jumlah 23 siswa.

Berdasarkan perhitungan data post-test diketahui bahwa nilai rata-rata kemampuan pemecahan masalah matematis yang diperoleh siswa sebesar 70,35 dengan simpangan baku sebesar 13,01. Dari 23 siswa kelas VIII.3 nilai tertinggi diperoleh sebesar 94 dan nilai terendah sebesar 46. Dari nilai rata-rata siswa dapat diketahui bahwa kemampuan pemecahan masalah matematis siswa dalam kategori baik.

Berdasarkan perhitungan data presentase nilai setiap indikator pemecahan masalah dapat dilihat pada Tabel 2: 


\section{Journal of Mathematics Science and Education \\ ISSN (Print) 2623-2375 | ISSN (Online) 2623-2383 | \\ DOI : https://doi.org/10.31540/jmse.v3i1.1097 \\ Penerbit : LP4MK STKIP PGRI Lubuklinggau}

Tabel 2. Deskripsi Kemampuan Pemecahan Masalah

\begin{tabular}{|l|c|c|}
\hline $\begin{array}{c}\text { Kategori Kemampuan } \\
\text { Pemecahan Masalah }\end{array}$ & Jumlah Siswa & Persentase \\
\hline Sangat baik & 5 & $21,74 \%$ \\
\hline Baik & 13 & $56,52 \%$ \\
\hline Cukup & 5 & $21,74 \%$ \\
\hline
\end{tabular}

Kemampuan pemecahan masalah dalam ketegori sangat baik mempunyai rentang nilai dari 84-94, siswa yang mendapatkan nilai sangat baik adalah siswa yang mampu menyelesaikan 4-5 soal dengan kemampuan pemecahan masalah sesuai indikator yang ada yaitu mampu memahami masalah, mampu membuat rencana penyelesaian, melakukan perhitungan dengan benar dan memeriksa kembali hasil kebenarannya, tidak banyak jumlah siswa yang mampu menyelesaikan dengan baik semua indikator pemecahan masalah, karena kurang aktifnya siswa dalam bertanya dan siswa kurang memperhatikan apa yang disampaikan oleh peneliti. Kemampuan pemecahan masalah dalam ketegori kurang dengan rentang nilai 46-56, siswa yang mendapatkan nilai kurang karena kurangnya minat dan semangat dalam belajar membuat siswa tersebut tidak menyelesaikan dengan baik soal-soal kemampuan pemecahan masalah yang diberikan dan kurangnya keberanian untuk bertanya dalam belajar serta ketika peneliti menyampaikan informasi atau pengetahuan tidak diperhatikan.

\section{KESIMPULAN}

Berdasarkan hasil penelitian dan pembahasan disimpulkan bahwa kemampuan pemecahan masalah matematis pada pembelajaran matematika menggunakan Pendekatan Pendidikan Matematika Realistik Indonesia (PMRI) dalam kategorikan baik. Rata-rata nilai dengan jumlah presentase siswa yang memiliki kategori baik dalam kemampuan pemecahan masalah sebesar 70,35 setelah diterapkan pembelajaran dengan Pendekatan Pendidikan Matematika Realistik Indonesia (PMRI). Setelah melakukan perhitungan uji hipotesis diperoleh $t_{\text {hitung }}=3,45$ dengan $t_{\text {tabel }}=1,72$ hal ini menunjukan bahwa $t_{\text {hitung }}<\mathrm{t}_{\text {tabel }}$ yaitu 3,45 $<1,72$ sehingga dapat dinyatakan $H_{o}$ ditolak dan $H_{a}$ diterima. 


\section{Journal of Mathematics Science and Education \\ ISSN (Print) 2623-2375 | ISSN (Online) 2623-2383 | \\ DOI : https://doi.org/10.31540/jmse.v3i1.1097 \\ Penerbit : LP4MK STKIP PGRI Lubuklinggau}

\section{DAFTAR RUJUKAN}

Daryati, Dewi, Nugraha, Nani Sutarni. (2018). Pengaruh Penggunaan Metode Problem Posing terhadap Kemampuan Pemecahan Masalah. Jurnal Pendidikan Ilmu Sosial. 27 (1). 31-42.

Indriani, M.N \& Imanuel. (2018). Pembelajaran Matematika Realistik Dalam Permainan Edukasi Berbasis Keunggulan Lokal Untuk Membangun Komunikasi Matematis. Prisma, Prosiding Seminar Nasional Matematika. 256-262.

Rahayu, R. (2017). Pembelajaran Matematika Realistik Indonesia Berbasis Keunggulan Lokal Untuk Membangun. Prosiding Seminar Nasional 15 Maret 2017. 152-163.

Rahman, A. A. (2017). Pengembangan Perangkat Pembelajaran Berbasis Pendekatan Realistik Untuk Meningkatkan. Jurnal MAJU. 4 (1).26-37.

Romauli, M. (2013). Pengaruh Pembelajaran Matematika Realistik dan Berfikir Logis Terhadap Hasil Belajar Matematika Siswa SD Bharlind School Medan. Jurnal Tematik.Prisma 1. 258-262. 